\title{
Strength Properties of Concrete with M-Sand as Fine Aggregate Incorporating with Acrylic Fiber
}

\author{
M. Devi, S. Shyamala Rubini, G. Soundarya, M. Srimegala, M. Tharageshwari
}

\begin{abstract}
The river sand is the natural sort of fine aggregate material which is employed within the concrete and mortar. It's usually obtained from the river bed and mining has disastrous environment consequences. Rather than the river sand we are using $M$-sand as fine aggregate within the concrete. The event of acrylic concrete marks a crucial milestone in improving the merchandise quality and efficiency of the concrete. Usage of acrylic within the concrete will increase the strength and durability of the concrete. It enhances the performance of the concrete and increase energy absorption compared with plain concrete. Within the present work we are getting to analysis the strength properties of fiber reinforced $M$-sand concrete like compressive strength, flexural strength, split tensile strength, and bond strength.
\end{abstract}

Keywords : concrete, manufactured sand, acrylic fiber, and strength.

\section{INTRODUCTION}

Concrete is that the most generally used construction material within the world, which is usually consists of cement, aggregates and water. It's the fiber, which is employed quite the other artificial material on the world for construction works. Short discrete fiber within the fiber reinforced concrete which is randomly oriented and uniformly distributed. There are different types of fiber with varying properties that includes steel fiber, glass fiber, synthetic fiber and natural fiber. Fiber material, geometries, distribution, orientation and densities are changed by the fiber reinforced concrete. The fiber reinforced concrete is used to reduce cracking due to plastic shrinkage and drying shrinkage. The permeability of concrete is reduced and so bleeding is reduced. In concrete, shatter resistance, abrasion and impact

Revised Manuscript Received on March 17, 2020.

* Correspondence Author

Dr.M.Devi*, Professor, Department of Civil Engineering, Vivekanandha College of Technology for Women, Tiruchengode, India. Email:devimcivil@gmail.com

S.Shyamala rubini, UG Student, Department of Civil Engineering, Vivekanandha College of Technology for Women, Tiruchengode, India. Email:rubinishyamala968@gmail.com

G.Soundarya, UG Student, Department of Civil Engineering, Vivekanandha College of Technology for Women, Tiruchengode, India. Email:gsoundarya43@gmail.com

M.Srimegala, UG Student, Department of Civil Engineering, Vivekanandha College of Technology for Women, Tiruchengode, India. Email:srimegala1999@gmail.com

M.Tharageshwari, UG Student, Department of Civil Engineering, Vivekanandha College of Technology for Women, Tiruchengode, India. Email:mtharageshwari@gmail.com

(C) The Authors. Published by Blue Eyes Intelligence Engineering and Sciences Publication (BEIESP). This is an open access article under the CC BY-NC-ND license (http://creativecommons.org/licenses/by-nc-nd/4.0/) is improved by adding some type of fiber. Recently, residual strength and controlled cracking are improved by adding fiber in the concrete. New attempt has been made to increases the strength and decreases the crack but still there are few narrow cracks in FRC. Polymer fiber is modified as acrylic fiber. It gratly increases the performance and also increases the durability of concrete. Plastic shrinkage cracking was reduced. It increases impact resistance and also provide secondary reinforcement.

\section{LITERATURE REVIEW}

Kuldeep Kumar, Er.Ritu [1] The strength of concrete is not the main concern. The main aim is to satisfy capillary absorption, high flexural strength, controlled cracking less porous, durability and less shrinkage. Acids and alkalis are resisted by acrylic fiber and the cost of the fiber is very low. Fiber reinforced concrete is one of the greatest application in structural field. The fiber reinforced concrete yields a positive effect and also satisfies various properties of concrete. R.Ilangovan, N.Mahendran, K.Nagamani [2] the compressive strength, flexural strength and durability properties of concrete made of quarry dust which is replaced of natural sand is more when compared to conventional concrete. S.Muralikrishnan, T.Felix Kala, P.Asha, S.Elavenil [3] based on the study, a comparison is made between natural and manufactured sand which gives strength and durability properties. In this project a performance analysis was done to determine the influence of $\mathrm{M}$-sand as fine aggregate in Metakaolin incorporated concrete. This paper presents the mechanical behavior of the selected fine aggregate, followed by the durability behavior of conventional and M-sand concrete. T.Shanmugapriya, R.N.Uma [4] the researches had been concluded that the improvement of compressive and flexural strength of concrete can be done by partial replacement of cement by silica fume and natural sand by manufactured sand. $50 \%$ of naural sand is replaced by manufactured sand. Luiz A.Pereira-de-Oliveira, João P.Castro-Gomes, Miguel C.S.Nepomuceno [5] the main objectives of this research is therefore to study the behavior of cement mortar specimen reinforced with acrylic fibers. The effect of aspect ratio $(\mathrm{l} / \mathrm{d})$ and volume fraction $\left(\mathrm{v}_{\mathrm{f}}\right)$ of acrylic fibers on compressive and flexural strength were asset. For this purpose acrylic fibers volume were added to mortar mix at $0.2 \%, 0.5 \%$ and $1 \%$.

\section{MATERIAL PARAMETER}

For this investigation concrete cubes of size $150 \mathrm{~mm}$ x $150 \mathrm{~mm}$ $\mathrm{x} 150 \mathrm{~mm}$, concrete cylinder of size $150 \mathrm{~mm}$ diameter and $300 \mathrm{~mm}$ long and prism specimens of size $100 \mathrm{~mm} \times 500 \mathrm{~mm}$, were casted.

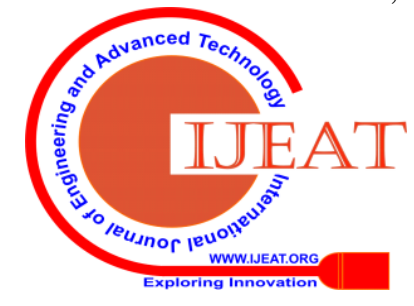




\section{A. Cement}

In the presence of water, cohesive and adhesive properties of cement is called hydraulic cement. This consists of primarily silicates and aluminates of lime obtained from limestone and clay. Ordinary Portland cement (OPC) is one the type of cement. It is generally used in construction field. It's of three types 33 grade, 43 grade, 53 grade. The main advantage of the cement is to bind other materials to give bonding strength. Ordinary Portland cement (OPC) available in the market conforming to IS 12269-1987 was used for casting the specimens. The cement used is 53 grade.

Table I. Chemical Composition (\%) of Cement

\begin{tabular}{|c|c|}
\hline Composition & OPC 53 grade \\
\hline $\mathrm{SiO}_{2}$ & 21.52 \\
\hline $\mathrm{Al}_{2} \mathrm{O}_{3}$ & 6.16 \\
\hline $\mathrm{Fe}_{2} \mathrm{O}_{3}$ & 4.60 \\
\hline $\mathrm{Cao}$ & 63.36 \\
\hline $\mathrm{Mgo}$ & 0.83 \\
\hline $\mathrm{So}_{3}$ & 1.87 \\
\hline $\mathrm{IR}$ & 1.30 \\
\hline Loss of ignition & 1.64 \\
\hline
\end{tabular}

\section{B. Fine aggregate}

It should be passed through IS sieve $4.75 \mathrm{~mm}$. It should have fineness modulus 2.50-3.50 and slit contents should not be more than $4 \%$. The fine aggregate used in this investigation is manufactured sand which is also called M-sand. Manufactured sand has been regularly used to make good quality of concrete for many years in india and abroad. In order to produce M-sand, the hard granite stones are crushed which is washed, cubical in shape and graded with consistency. It confirms to IS 383-1970 which comes under zone II.

Table II. Physical Properties of Fine aggregate

\begin{tabular}{|c|c|}
\hline Specific gravity & 2.54 \\
\hline Water absorption & $11 \%$ \\
\hline
\end{tabular}

\section{Coarse aggregate}

It should be strong, durable, hard, clean and dense. It mean be free from vein, adherent coatings and injurious amount of disintegrated pieces, alkalis, vegetable matters and other deleterious substances. It should be roughly cubical in shape. Flaky pieces should be avoided. It should confirm to IS 2838(I). Two sizes of $12.5 \mathrm{~mm}$ minimum size and $20 \mathrm{~mm}$ maximum size of coarse aggregate were used.

Table III. Physical Properties of Course aggregate

\begin{tabular}{|c|c|}
\hline Specific gravity & 2.778 \\
\hline Water absorption & $0.25 \%$ \\
\hline
\end{tabular}

\section{Water}

Water should be free from vegetables, oils, acids, alkalies or other organic impurities. Soft waters also produce weaker concrete. Water has two functions during a concrete mix. Firstly, to make the cement paste during which inert aggregate are held in suspension, it reacts chemically until the cement paste is hardened. Secondly, it serves as a lubricant within the mixture of fine aggregates and cement.

\section{E. Superplastizer}

In order to improve the workability of high performance concrete, superplasticizer in the form of poly-carboxylic either based superplasticizer (Glenium 8233) was used as chemical admixture. The product has specific gravity of 1.08 and solid content not less than $30 \%$ by weight of cementitious material.

\section{F. Acrylic fiber}

Acrylic fibers is one of the synthetic fibers which is made up of a polymer (polyacrylonitrile) and it has mean molecular weigth of 1900 monomer units. The fiber used for making sweater, tracksuite and lining are strong and warm. Application of acrylic fiber reinforced concrete utilized in construction. Utilization of low dosage of acrylic fiber enhances the flexural strength of the concrete which reduces cracking. By utilizing low dosage of acrylic fiber, the stronger element separate throughout the entire section which reduces the cracking and increases the flexural strength. During curing, the components are inherently stronger as the shrinkage crack are prevented by acrylic. Sometimes crack will propagate when the load is imposed on concrete which leads to failure. By adding of acrylic in concrete prevents/arrests cracking. The modulus of elasticity of acrylic fibre incorporated concrete is high when comparing with the modulus of elasticity of concrete without fibre. The modulus of elasticity of acrylic is high with reference to the modulus of elasticity of the concrete. Acrylic are eco-friendly and not poisonus. Acrylic fiber is added as $0.5 \%, 1 \%, 1.5 \%, 2 \% .2 .5 \%$ and $3 \%$ by weight of cement. It is added as an additive to improve it's performance and it's strength. Figure 1 represent the acrylic fiber used.

Table IV. Specification of acrylic fiber

\begin{tabular}{|l|l|}
\hline Diameter $(\mu \mathrm{m})$ & 14.4 \\
\hline Length $(\mathrm{mm})$ & 1.55 \\
\hline Density $\left(\mathrm{kg} / \mathrm{m}^{3}\right)$ & 1170 \\
\hline Tensile strength $\left(\mathrm{N} / \mathrm{mm}^{2}\right)$ & 690 \\
\hline Elongation $(\%)$ & $15-20$ \\
\hline Acid resistance & Excellent \\
\hline Alkali resistance & Good \\
\hline
\end{tabular}

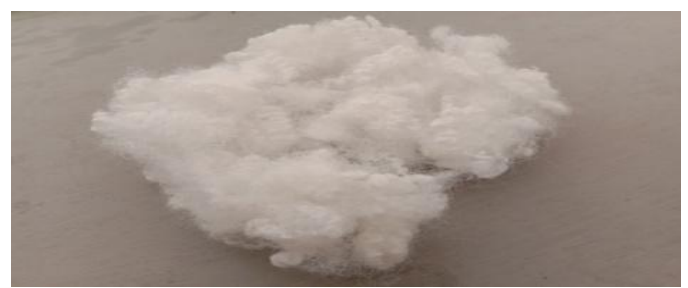

Figure 1.Acrylic Fiber

\section{G. Mix design}

The concrete mix is designed as per IS 10262-1982, IS 456-2000 and SP16 for the conventional concrete and finally river sand is replaced by $\mathrm{M}$-sand. The water cement ratio and the mix proportions of M50 concrete with ratio of 1:1.472:3.043.

Published By:

Blue Eyes Intelligence Engineering \& Sciences Publication

(C) Copyright: All rights reserved.

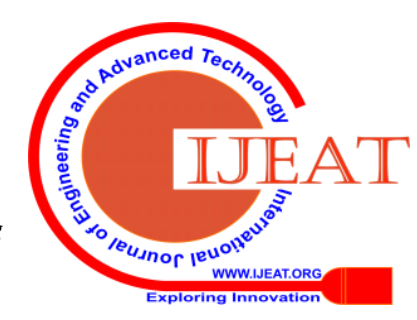




\section{EXPERIMENTAL INVESTIGATION}

The results obtained from experimental tests conducted on hardened concrete for conventional and acrylic fiber reinforced concrete with fiber dosages of $0.5 \%$, $1 \%, 1.5 \%, 2 \%, 2.5 \%$ and $3 \%$. Test details and results are discussed below.

\section{A. Compressive strength test}

Cube specimens of size $150 \mathrm{~mm}$ x $150 \mathrm{~mm}$ x $150 \mathrm{~mm}$ were cast for different dosage of acrylic fiber of $0.5 \%, 1 \%, 1.5 \%, 2 \%, 2.5 \%$ and $3 \%$. Results are tabulated in table 5 and plotted in the graph below,

Table V. Compressive Strength Results

\begin{tabular}{|c|c|c|c|}
\hline \multirow{2}{*}{$\begin{array}{c}\text { Percentag } \\
\text { e of acrylic } \\
\text { fiber } \\
\text { added }\end{array}$} & \multicolumn{3}{|c|}{ Compressive strength $\left(\mathrm{KN} / \mathrm{m}^{2}\right)$} \\
\hline & 7 days & 14 days & 28 days \\
\hline 0 & 43.2 & 45.62 & 47.25 \\
\hline 0.5 & 43.8 & 47.7 & 55 \\
\hline 1 & 44.5 & 48.03 & 56 \\
\hline 1.5 & 45.3 & 49.06 & 57.7 \\
\hline 2 & 46.6 & 49.4 & 58.7 \\
\hline 2.5 & 46.4 & 49.25 & 57.9 \\
\hline 3 & 42.1 & 44.4 & 45.6 \\
\hline
\end{tabular}

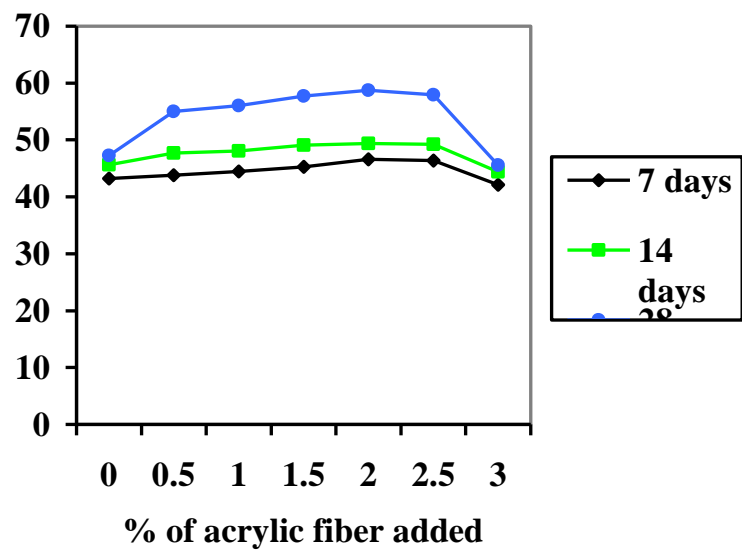

\section{B. Split tensile strength test}

Cylindrical specimens of size $150 \mathrm{~mm}$ diameter x $300 \mathrm{~mm}$ in height were cast for varying dosage of acrylic fiber at $0.5 \%$, $1 \%, 1.5 \%, 2 \%, 2.5 \%$ and $3 \%$ are tested for split tension. To obtained results are tabulated in table 6 and plotted in the graph below,

Table VI. Split Tensile Strength Results

\begin{tabular}{|c|c|c|c|}
\hline \multirow{2}{*}{$\begin{array}{c}\text { Percentag } \\
\text { e of acrylic } \\
\text { fiber } \\
\text { added } \\
\end{array}$} & \multicolumn{3}{|c|}{ Split tensile strength(N/mm²) } \\
\hline & 7 days & 14 days & 28 days \\
\hline 0 & 3.5 & 3.69 & 3.74 \\
\hline 0.5 & 4.01 & 4.28 & 4.93 \\
\hline 1 & 4.16 & 4.36 & 5.07 \\
\hline 1.5 & 4.32 & 4.44 & 5.2 \\
\hline 2 & 4.53 & 4.52 & 5.26 \\
\hline 2.5 & 4.45 & 4.47 & 5.12 \\
\hline 3 & 3.32 & 3.45 & 3.69 \\
\hline
\end{tabular}

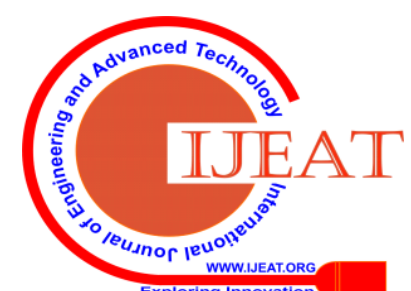

\begin{tabular}{|c|c|c|c|}
\hline \multirow{2}{*}{$\begin{array}{l}\text { Percentage of } \\
\text { acrylic fiber } \\
\text { added }\end{array}$} & \multicolumn{3}{|c|}{ Flexural strength(N/mm²) } \\
\hline & 7 days & 14 days & 28 days \\
\hline 0 & 3.5 & 3.69 & 3.74 \\
\hline 0.5 & 4.01 & 4.28 & 4.93 \\
\hline 1 & 4.16 & 4.36 & 5.07 \\
\hline 1.5 & 4.32 & 4.44 & 5.20 \\
\hline 2 & 4.53 & 4.52 & 5.26 \\
\hline 2.5 & 4.45 & 4.47 & 5.12 \\
\hline 3 & 4.32 & 3.45 & 3.69 \\
\hline
\end{tabular}

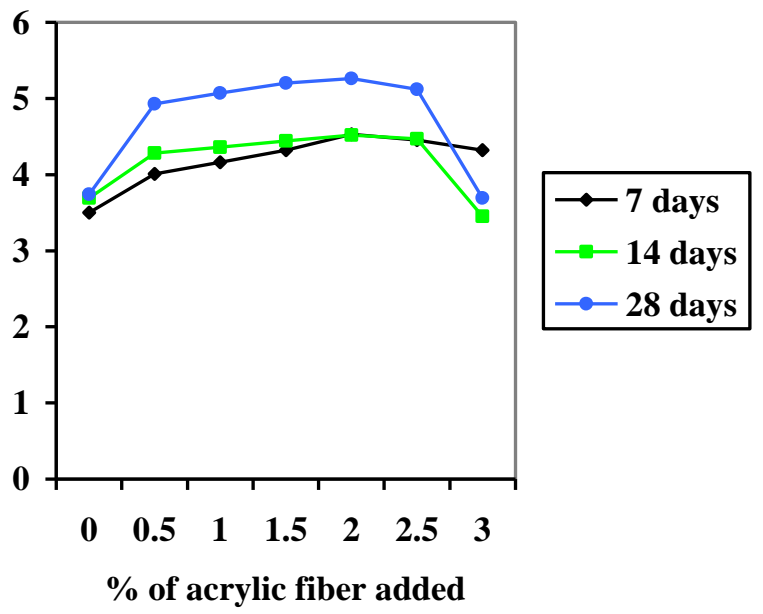




\section{Bond strength test}

In this test the bond strength is expressed in terms of the average bond stress obtained from pullout test. The force around the embedded length is calculated through universal testing machine (UTM) and the average bond stress is calculated and the test results are tabulated. Table 8 shows the bond stress and slip values obtained during the experiment for the high strength concrete i.e. M50 grade of concrete.

Table VIII. Bond Strength Results

\begin{tabular}{|c|c|c|c|}
\hline \multirow{2}{*}{$\begin{array}{c}\text { Percentage of } \\
\text { acrylic fiber } \\
\text { added }\end{array}$} & \multicolumn{3}{|c|}{ Bond stress in(N/mm²) } \\
\cline { 2 - 4 } & 7 days & 14 days & 28 days \\
\hline 0 & 5.10 & 5.63 & 5.80 \\
\hline 0.5 & 5.36 & 5.85 & 6.37 \\
\hline 1 & 5.76 & 6.16 & 7.08 \\
\hline 1.5 & 6.02 & 6.29 & 7.48 \\
\hline 2 & 6.69 & 6.82 & 7.57 \\
\hline 2.5 & 6.50 & 6.52 & 7.50 \\
\hline 3 & 4.82 & 4.85 & 4.90 \\
\hline
\end{tabular}

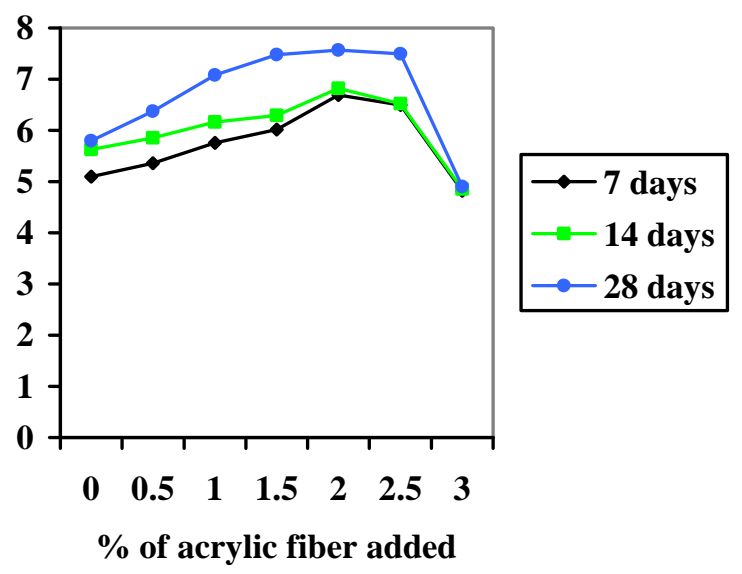

\section{CONCULSION}

The following important conclusions were drawn based on the results obtained from the above mentioned tests,

- By increasing the addition of acrylic fiber dosages from $0 \%$ to $0.5 \%, 1 \%, 1.5 \%, 2 \%, 2.5 \%$ and $3 \%$, the workability decreases. Hence, superplasticizer (Glenium 8233) was used in the dosage of $10 \mathrm{ml}$ to improve the workability.

- When compared to conventional concrete, compressive strength of M50 grade for varying dosages of acrylic fiber at $0.5 \%, 1 \%, 1.5 \%, 2 \%, 2.5 \%$ and $3 \%$, increased compressive strength respectively. The maximum percentage increase in compressive strength was achieved at $2 \%$ of fiber dosage and was found to reduce for $2.5 \%$ of fiber content.

- It was also observed that there was an increase in split tensile strength for varying dosages of $0.5 \%, 1 \%, 1.5 \%$, $2 \%, 2.5 \%$ and $3 \%$ and were found to be increased in split tensile strength than that of conventional concrete. The maximum percentage in split tensile strength was achieved at $2 \%$ of fiber dosage and was found to reduce for $2 \%$ of fiber content.

- Flexural strength of M50 grade of concrete for different dosage of acrylic fibers at $0.5 \%, 1 \%, 1.5 \%, 2 \%, 2.5 \%$ and $3 \%$ when compared with conventional concrete was found to increased in flexural strength respectively. The maximum percentage increase in flexural strength was achieved at $2 \%$ of fiber dosage and was found to reduce for $2.5 \%$ of fiber content.

- The bond strength increased as the amount of concrete surrounding the reinforcing bar increased. The maximum bond strength was attained at $2 \%$ whereas the minimum bond strength was occurred at $3 \%$.

- From the results it is observed that there is an increase in strengths (compressive, split tensile, flexural, bond strength tests) up to $2 \%$ of fibers by weight of concrete and decreases for $2.5 \%$ addition of fiber.

\section{REFERENCES}

1. Kuldeep Kumar, Er. Ritu "Effect of acrylic fiber on the flexura strength and durability of pavement quality concrete: A review" International Journal of Technical Research" vol. 4, 2015.

2. R. Ilangovan, N. Mahendrana, K. Nagamani "strength and durability properties of concrete containing quarry rock dust as fine aggregate" APRN Journal of Engineering and Applied Sciences, vol. 3, no. 5, 2008.

3. S. Muralikrishnan, T. Felix kala, P. Asha, S. Elavenil "Properties of concrete using manufactured sand as fine aggregate" International Journal of ChemTech Research, vol.9, pp. 94-100, 2018.

4. T. Shanmugapriya, R.N. Uma, "Optimization of Partial Replacement of M-sand by Natural sand in HPC with silica fume" International Journal of Technology of Engg Sciences \& Emerging Technologies, vol. 2, pp. 73-80, 2012.

5. Luiz A. Pereira-de-Oliveira, João P. Castro-Gomes, Miguel C.S. Nepomuceno "Effect of Acrylic fibers geometry on physical, mechanical and durability properties of cement mortars" Construction and Building Materials, vol. 27, pp. 17-68, 2012.

6. U.Bhavitha, Mohammed Safiuddin, and Syed Mohsin "Study of strength properties of polyster fiber reinforced concrete" Journal of research, vol 2, 2016.

7. M.Prabu, I.Mohammedrafi, and M. Sathees Kumar "Experimental investigation on concrete using recron fiber as reinforcement" international journal of innovation research in science, engineering and technology, vol 8, 2019.

8. Aishwarya Sukumar, and Elson John "Fiber addition and its effect on concrete strength" Inernational journal of innovative research in advanced engineering, vol 1, 2014.

\section{AUTHORS PROFILE}

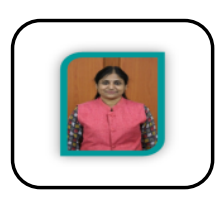

Dr.M.Devi M.E., Ph.D., I am working as Dean Student Affairs \& Head of the department of Civil Engineering in Vivekanandha College of Technology for women, Tamilnadu. I am having 20 years of experience in engineering colleges. I have published 20 papers in reputed journals and presented papers in international conferences in USA, Dubai, Singapore and Thailand. I also attended workshops in NASA and Widener University in Philadelphia in USA. I have membership in 8 professional bodies and also Anna University recognized research Supervisor and received more than 10 awards in research and women empowerment etc.

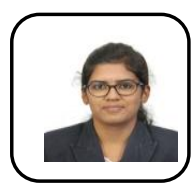

S.Shyamala Rubini . I am studing under graduate in department of civil engineering, Vivekanandha College of Technology for Women, Tiruchengode. I completed higher secondary school at shri ganga higher secondary school, Ingur. I have successfully completed the program requirements of AUTOCAD at Vivekanandha

Educational Institutions,

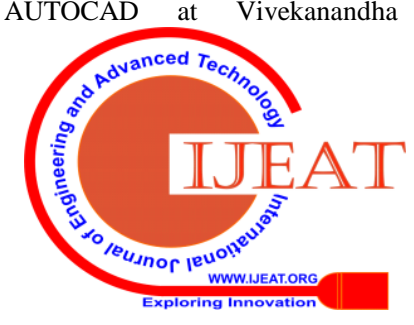


Nammakal. I am one of member of Indian Concrete Institute. I attended 4 workshops in various colleges and I participated one National Level Student's Technical meet. I attend one implant training in G.K.engineering, Coimbatore and I also attended one International conference based on my project.

G.Soundarya. I am studying under graduate in department of civil engineering, Vivekanandha College of Technology for Women, Tiruchengode. I completed higher secondary school at brindhavan higher secondary school, pattukottai. I have successfully completed the program requirements of AUTOCAD at Vivekanandha Educational Institutions, Nammakal. I am one of member of Indian Concrete Institute. I attended 2 workshops in various colleges. I attended one International conference based on my project.

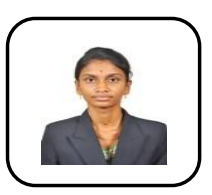

M.Srimegala. I am studying under graduate in department of civil engineering, Vivekanandha College of Technology for Women.Tiruchengode. I completed higher secondary school at vidhya nikethan intel matric higher secondary school, Rasipuram. I have successfully completed the program requirement of AUTOCAD, REVIT and STAADPRO in salem. I am one of the member of Indian Concrete Institute. I attended 4 workshops and 2 national seminars. I presented a presentation and got $1^{\text {st }}$ prize in salem college. I attended 4 inplant training and I also attended one international conference based on our project.

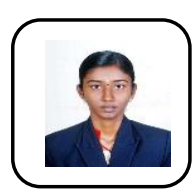

M.Tharageshwari. I am studying under graduate in department of civil engineering, Vivekanandha College of Technology for Women.Tiruchengode. I completed higher secondary school at Vivekanandha vidyalaya matric higher secondary school, muthur. I have successfully completed the program requirement of AUTOCAD and REVIT ARCHITECTURE at penta cad, erode. I am one of the member of Indian Concrete Institute. I attended 3 workshops and 1 technical symposium. I attended 2 inplant training, one in shree thirumalai construction, nammakal and other in public work department, dindugal and I also atended one international conference based on our project.

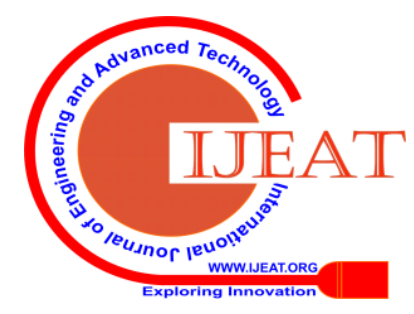

